\title{
Revisionism: The Provisional Republican Movement
}

\author{
Robert Perry \\ Phd (Queens University Belfast) MA, MSSc \\ 11 Caractacus Cottage View, Watford, UK \\ Tel: +44 $01923350994 \quad$ E-mail: robert.perry@ntlworld.com
}

\begin{abstract}
This article explores the developments within the Provisional Republican Movement (IRA and Sinn Fein), its politicization in the 1980s, and the Sinn Fein strategy of recent years. It discusses the Provisionals' ending of the use of political violence and the movement's drift or determined policy towards entering the political mainstream, the acceptance of democratic norms. The sustained focus of my article is consideration of the revision of core Provisional principles. It analyses the reasons for this revisionism and it considers the reaction to and consequences of this revisionism.
\end{abstract}

Keywords: Physical Force Tradition, Armed Stuggle, Republican Movement, Sinn Fein, Abstentionism, Constitutional Nationalism, Consent Principle

\section{Introduction}

The origins of Irish republicanism reside in the United Irishman Rising of 1798 which aimed to create a democratic society which would unite Irishmen of all creeds. The physical force tradition seeks legitimacy by trying to trace its origin to the 1798 Rebellion and the insurrections which followed in 1803, 1848, 1867 and 1916. Sinn Féin (We Ourselves) is strongly republican and has links to the IRA. The original Sinn Féin was formed by Arthur Griffith in 1905 and was an umbrella name for nationalists who sought complete separation from Britain, as opposed to Home Rule. The current Sinn Féin party evolved from a split in the republican movement in Ireland in the early 1970s. Gerry Adams has been party leader since 1983, and led Sinn Féin in mutli-party peace talks which resulted in the signing of the 1998 Belfast Agreement.

\section{Birth of the Provisionals}

"The decision to end the resistance campaign has been taken in view of the general situation. Foremost among the factors motivating this course of action has been the attitude of the general public, whose minds have been deliberately distracted from the supreme issue facing the Irish people - the unity and freedom of Ireland". (Note 1)

Thus the IRA's campaign, which had lasted from 1956 to 1962, was officially called off. While an indifferent and often hostile nationalist population in the North watched, the campaign was bound to end in failure and recrimination, the gun would go back on the shelf and for republicans Ireland would remain divided and unfree. Although the IRA had had a political wing, Sinn Fein, it had failed to see the importance of mobilizing this political organization in conjunction with its military push. Political action was neglected for an exclusive concentration on physical force.

Gerry Adams (Note 2) emphasized that the failure of the 1950s campaign had a profound effect on those who remained active during the 1960s. Within the Republican movement there was a review. Republicans were to consider why the movement was not getting support. When the leadership conducted its review, they found that the base of support was vanishing and that the struggle was divorced from the daily lives of the people. In his book The Politics of Irish Freedom (1986) Adams was to elaborate on this internal analysis:

"What came most clearly from these discussions was recognition that republicans needed to identify their philosophy as being relevant not to the vision of a future Ireland, but to the actual Ireland of today, and that they needed to enlist mass support... for the republican cause". (Note 3)

Therefore, what emerged in 1960s Ireland was a radical form of republicanism. It had become dominant within the Republican movement because those who were opposed to it had simply no alternative to offer. A socialist republic was adopted as the final goal of the movement, which stressed the need for the movement to become involved in the struggles of 'ordinary people' over housing, rents, fishing rights, and civil rights. However, these changes did not represent a replacement of militarism by political action. Nonetheless, there were those who opposed what they considered to be an alien Marxist ideology which was absorbing Irish republicanism. 
It was the events of 1969 which acted as the catalyst for a split within the Republican Movement. A majority of people were to blame the IRA for the failure to defend nationalist areas. The troubles meant that the movement had mushroomed and with these new members came criticism of the leadership over its lack of defense and its policy of de-militarization. All this was to over-shadow the 1970 Ard Fheis (Party conference). Although abstentionism (Note 4) had failed to get the necessary two thirds vote, at the conference, and was thus not passed, the issue had brought Thomas Maguire, the sole surviving member of the Second Dail Eireann of 1921, to condemn the dropping of the abstentionist policy by the 1969 IRA Convention and declare it 'illegal'. He also declared the Provisional Army Council as the 'lawful executive' and the 'legitimate successors' to the Second Dail, thus the First Dail, thus the men of 1916. With the birth of the Provisionals came the return of the Old Guard, with its conservatism and its adherence to republican orthodoxy. (Note 5) True, there were those of a leftist position within the Provisionals; but they were few. For they were to be members of a movement which would once again exorcise politics from its midst.

\section{Ballot and Armalite}

When the Provisionals were formed, all effort was put behind the military struggle, with Sinn Fein being relegated to the poor relation within the republican family. The Party was developed as essentially a support group for the military wing and Sinn Fein would provide a legal platform for the IRA to operate openly. An IRA re-organization document in 1977, which was believed to have been the work of Gerry Adams among others, stressed that Sinn Fein should have a more active role, should be radicalized and agitate about social and economic issues, but would still be the subordinate to the 'Army' and should come under IRA organizers at all levels. (Note 6)

The general assumption which was prevalent at the time was that 'the war' would be of short duration. As the traditionalists had parted from radical republicanism via the split, there was to be no variant of it in the Provisionals. A do-not-touch approach was firmly adopted towards abstentionsim. As it became increasingly obvious that there was not going to be a 'quick war', new strategies would have to be adopted. The developing of a strong political expression which would be a serious electoral contender would have to be a priority. The Old Guard knew too well, for they had gone down this road before, that soon, too, the 'sacred cow' of republican abstentionism would be placed very much within the centre of that debate. Attempts to build Sinn Fein into a recognizable, political party obviously meant that an electoral strategy would be crucial. The death of the MP for Fermanagh and South Tyrone, in 1981 was to offer a situation to advance such a strategy. At the Ard Fheis prior to the election of Bobby Sands and the Leinster House election victories of Kieran Doherty and Paddy Agnew, the majority view was not to get involved in elections. After these examples of success, the next Ard Fheis was to have a different attitude. At the Sinn Fein Ard Fheis in 1981 Danny Morrison, a leading ally of Adams, was to comment:

"Who here really believes that we can win the war through the ballot box? But will anyone here object if, with a ballot paper in this hand, and an Armalite in this hand, we take power in Ireland?" (Note 7)

The next step was to allow the party executive the decision as to whether to contest elections in the North and South on an abstentionist basis. And in 1983 Gerry Adams was to replace Ruairi O'Bradhaigh as president of Sinn Fein. On his take-over Adams was to declare: 'we are an abstentionist party; it is not my intention to advocate change in this situation'. However, electoralism like all the other policy changes was to face opposition and the May 1985 council elections represented such a challenge. A good result was needed, so as not to serve as an embarrassment for the movement. Adams himself made projections of 35 council seat victories. The actual outcome was near 60 seats.

Side by side with this 'Ballot Box/Armalite' strategy was the view that the South was the key in the successful conclusion of the struggle. Many believed that there was a good chance of gaining seats in Leinster House (The Parliament in the Irish Republic) in several border and inner city constituencies. The Hunger Strike had had a profound effect on the attitude of many in the Republican movement regarding electoralism and attempts to build a political party. It had witnessed an upsurge of popular support for the movement which was translated into votes. The election of Gerry Adams as MP for West Belfast in 1983 and again in 1987, the 11 Sinn Fein councilors elected for Greater Belfast, and the advice centers - many wanted to see this happening in the South.

Breaking out of isolation and becoming politically relevant, together with the need to blend the national struggle with contemporary reality as perceived by the majority of the people in the 26 Counties, was essentially the argument forwarded by those who advocated the dropping of abstentionism. The basic fact was that people in the 26 Counties did not see any point in electing candidates who would not take their seats.

In relation to the 1986 Sinn Fein and Republican Sinn Fein split, divisions between the two groups were to be inherent within the Provisional movement right from its inception. The 'Old Guard', who were tied to republican tradition and orthodoxy, had been thrown together with a younger element whose main concern was the 'defense' of their communities. While the waging of the 'war' was seen in purely militaristic terms, all the divisions and differences could be pushed aside. However, with the re-evaluation process which had started in the late 1970s, but was to really get underway in the early and mid 1980s, all the dissent, disagreement and division was to come out into the open. While 
this was going on, some voices within the nationalist family were attempting to wean the Provisionals away from violence.

\section{Hume-Adams}

"They are the pure master race of Irish. They are the keepers of the holy grail of the nation. That deep-seated attitude, married to their method, has all the hallmarks of undiluted fascism...If I were to lead a civil rights campaign in Northern Ireland today, the major target of that campaign would be the IRA". (Note 8)

The above quotations are from a speech that John Hume (SDLP leader) made at his party's 1988 annual conference. The question is why, therefore, did he engage in dialogue, and initiate a peace process, with the Sinn Fein leader? (Note 9) John Hume was to stress that it should not be forgotten that the Provisional IRA was a product of the traditional nationalist philosophy, a philosophy that was associated in essence with the 'noble act' of 1916, and that all the major parties in the Republic of Ireland originated from that philosophy. He was firmly of the view that if Ireland was to see lasting peace, the attitude and methods of the Republican movement (IRA/Sinn Fein) would have to be addressed.

In their first joint statement of 1993 Gerry Adams was to agree with John Hume that while the Irish people as a whole had a right to self-determination, they were divided as to how that right to self-determination was to be exercised - thus suggesting that Sinn Fein could foresee an end to British sovereignty in Ireland, but the partition of Ireland would still be a reality. Certainly this represented a radical departure from their anti-partitionist platform. Hume was determined in his talks with Adams to win over the Republican movement to a total cessation of violence, and to establish a dialogue process. This process would in effect involve all parties, including Sinn Fein, who would commit themselves to the promotion of agreement between the different traditions in Ireland, and that it was for the Irish people alone to decide what form this agreement would take. Hume argued that the Anglo-Irish Joint Declaration of December 1993 was the end result of the above process: he stressed that, in the agreement, the British government declared that it no longer had any selfish, strategic or economic interests in Ireland, that it was committed to promoting agreement between the divided people of Ireland, and that any agreement that was to emerge would be legislated for. Hume was to declare that this represented 'clear self-determination'.

Following the accession of Albert Reynolds (to the office of An Taoiseach and leader of Fianna Fail) in February 1992, the strategy of trying to involve Sinn Fein in the political process became central to government policy. For the previous two decades the central objective of Irish government policy had been to isolate Sinn Fein and support constitutional nationalism through the SDLP. One of the main objectives of the 1985 Anglo-Irish Agreement was to shore up the SDLP against the resurgence of Sinn Fein, following the Hunger Strike. However, government policy underwent a sea-change in the early 1990s. Instead of trying to crush Sinn Fein and keep the Party isolated, the Reynolds government built links with republicans and sought to develop a political approach that would bring an end to the IRA campaign by all-inclusive talks.

Sinn Fein showed a favorable response to the Framework Document of 1995 . The party was of the view that the political framework envisaged was an all-Ireland one. In the Framework for Accountable Government in Northern Ireland political institutions were envisaged that would be:

Widely acceptable, in particular in the sense of providing an appropriate and equitable role for both sides of the community, such that both the main parts of the Northern Ireland community should be able to identify with them and feel that their representatives had a meaningful function to perform.

The other document which was part of the Framework package was A New Framework for Agreement which most pleased the Provisionals. It:

Proposed a North/South body, comprising elected representatives from, and accountable to, a Northern Ireland Assembly and the Irish parliament, to deal with matters designated by the two governments in the first instance in agreement with the parties.

For nationalists the Framework proposals offered a genuine democratic Northern Ireland political entity, a strong, effective and executive North/South body and the inter-governmental conference in effect still policing the process. A new dispensation with no resonance whatsoever with the Stormont days, but an agreement that was in essence comparable to what was on offer to the Provisional Republican movement at the Sunningdale Agreement of 1974, i.e. 'power-sharing', and a 'Council of Ireland'.

\section{Towards an end to Conflict}

The Sinn Fein leadership was to recognize the narrow limits of the Party's support base in the South and the likelihood of a politically shrinking base in the North, and concluded that conditions would have to be created to enable a broader nationalist coalition to take place, involving Fianna Fail, the SDLP and the mobilization of international opinion against British policy in Ireland. It was apparent to the leadership of the Republican movement that such an alliance would mean an end to the IRA campaign. The 1987 document Scenario for Peace was to concern itself with setting out 
demands for a British withdrawal. It was to set out the conditions involved in the withdrawal. The document Towards a Lasting Peace in Ireland, published in 1992, indicated a real evolution in the republican analysis. It contains, amongst others, these points:

Sinn Fein would argue that if there is to be peace in Ireland, a Dublin government will have to assume its national responsibility. That responsibility must involve the Dublin government in developing a strategy aimed at persuading the British, the unionists and the international community of the disastrous failure of partition. Launching the document in Belfast, Adams was to say that they might have to accept 'interim phases and interim arrangements' (Note 10) while still clinging to the aspirations of a united Ireland.

The key to the republican analysis and strategy was spelled out in a confidential paper, sometimes referred to as the TUAS Document, which was circulated within the IRA and Sinn Fein in the summer of 1994. TUAS was widely believed at the time to mean 'Totally Unarmed Strategy', whilst acknowledging that the goal of a united 32-county democratic socialist republic had not changed:

"The main strategic objectives to move us towards that goal can be summarized thus: to construct an Irish nationalist consensus with international support on the basis of the dynamic contained in the Irish peace initiative. This should aim for: the strongest possible political consensus between the Dublin government, Sinn Fein and the SDLP..." (Note 11)

On August 12, 1994 Danny Morrison was to declare that the armalite and ballot box strategy was over. Morrison was to state that 'different times require different strategies'. (Note 12) Nineteen days later the Provisional IRA announced a total and complete ceasefire, beginning on September 1, 1994. A joint statement was issued by Albert Reynolds, John Hume and Gerry Adams, which declared:

We are at the beginning of a new era in which we are all totally and absolutely committed to democratic and peaceful methods of resolving our political problems. (Note 13)

Seventeen months later the IRA planted a bomb in London, killing two people and injuring over a 100 more. TUAS now meant 'Tactical Unarmed Strategy'. One is forced to conclude that the IRA cessation had taken place without any process of re-education being undertaken within the Republican movement to convert the militarism of many republicans to an exclusively political, democratic and legal method of pursuing their objective.

\section{Traditionalists and Socialist Republicans}

Hardliners and purists were of the view that a republican organization making such a fundamental change could no longer call itself republican. Republican Sinn Fein (RSP) believed that to take seats in Leinster House would mean accepting the apparatus of 'collaboration and repression'. For many in RSF that great corrupting nature of politics had indeed corrupted former comrades. Geraldine Taylor, RSF Ard Comhairle (party executive) stated: when RSF broke away from Sinn Fein in 1986, she asserted: 'we took the Republican movement with us because RSF alone has stood by republican principles'. (Note 14) Taylor slammed Sinn Fein as a 'revisionist party' that had 'sold out'.

On being asked whether RSF represent an electoral challenge to Sinn Fein in the republican heartlands of the North, she stated that in regards to local government elections in the Six Counties, the British government refused to accept RSF's nomination papers because the Party refused to sign the mandatory non-violence declaration for all parties and candidates. Therefore, at the local level there is no way of testing their strength. The 2007 Assembly election offered an opportunity for Geraldine Taylor to test the support for RSF in West Belfast when she stood against Gerry Adams in the constituency - she got 427 votes $1.3 \%$ of the vote whilst Sinn Fein got 23,631 votes 69.9\% of the vote in the West Belfast.

Not surprisingly RSF was to attack the peace strategy of Sinn Fein. It dubbed the Provisional movement as 'the Six-County wing of Fianna Fail' and 'the SDLP mark 2'. The Party claimed that the ceasefire became inevitable in 1986, when Sinn Fein ended its policy of abstentionism and looked to the Dublin administration for 'assistance'. Ruairi O'Bradaigh (President of RSF) proclaimed the Sinn Fein peace process as a 'betrayal', an abandonment of the republican ideal, "as the loyalist paramilitaries said when announcing their ceasefire, 'the union is safe' " (Note 15). The Provisional leadership, military and political, had, in effect, accepted the unionist veto.

At the time of its inception the Irish Republican Socialist Party (IRSP) argued that it had a valid platform, because the Provisionals at that time were traditional, conservative, occupied with physical force and very much underdeveloped in terms of politics and ideology. Many in the IRSP believed that if it could organize itself it would act as a vehicle for the emergent left in Ireland with its banner and programme of 'socialist republicanism'. However, the IRSP was never to recover from the Hunger Strike, because Sinn Fein was moving gradually towards the left. In its policies Sinn Fein is seemingly a left-wing party. Those who remained in the IRSP felt that the Provisional movement had stolen its clothes in a political and ideological sense.

The critique of the leadership of the IRSP of the Provisional movement is that it is elitist, that is determined to control all within its bounds, that they need to have the hegemony of the 'struggle', that they need to claim that they can speak 
with one voice on behalf of the entire community, and that they can deliver the ceasefire, deliver the peace, and that this necessitates the demise of the IRSP or any radical dissenting voice around which any dissident elements can gather in an organized fashion. (Note 16) The IRSP attacked the IRA ceasefire and Sinn Fein strategy. It declared that the republican position had been undermined and that the Irish people were being prepared for the acceptance of a newly revamped Northern state. In other words, a 'revamped Stormont' and a 'copper-fastened partition'. The IRSP is insistent that the very basis of republicanism has been put in jeopardy by the Provisional movement who has accepted the right of unionists to their consent to the unification of Ireland 'a veto for continued partition and an internal settlement'.

The next section moves on from the Provisionals' dominance within Northern nationalist heartlands to their attempt to ensure dominance within mainstream Northern nationalism.

\section{Party Rivalry - SDLP and Sinn Fein}

"I cannot believe what I am listening to. Tell me, are people here afraid of peace? ... John asked: do you want to keep the party alive or people alive?" (Note 17).

The above statement is from John Hume and it was reliably reported to have been made at a meeting in the South Belfast constituency office of the SDLP on August 18, 1994. Although Hume's leadership was not in question, there were doubts about the wisdom of persevering with a peace process with a political party that was not only the political expression of the Republican movement, which included the IRA, but was also a direct rival for votes.

Prior to the 1994 ceasefire the SDLP's raison d'etre was clear: it was the non-violent participatory wing of Irish nationalism. This was in marked contrast to the armalite ballot-box strategy of their main political rival. But the ceasefire would mean that points of difference with Sinn Fein were bound to disappear. If the two parties in terms of analysis and strategy appeared similar, i.e. non-violent, representation of the concerns and aspirations of Northern nationalists, then, inevitably, voters would support the party that was most identified with active campaigning on their behalf. Being identified as the only political party with an active profile in working class nationalist areas would provide electoral dividends for Sinn Fein.

A major difference between the SDLP and Sinn Fein is over Sinn Fein's policy of abstentionism. This dates back to Arthur Griffith's (the founder of Sinn Fein in 1905) summation of the Hungarian nationalists' campaign for independence from Austria in the nineteenth century as outlined in The Resurrection of Hungary: A Parallel for Ireland (1904). Griffith noted that the Hungarian nationalists adopted a policy of refusing to send their representatives to the Austrian parliament. Griffith argued that Irish nationalists should pursue the same policy. The policy of abstentionism since then became part of the Republican movement theology. Although in 1986, as has been noted, it was dropped for elections to the parliament in the South, and (as will be shown) was later dropped to elections to the Northern Ireland Assembly, it is still in operation for Westminster elections. A senior SDLP figure and first nationalist Lord Mayor of Belfast, Alban Maginness, contended that it was 'surely absurd' of Gerry Adams to seek votes from the long suffering people of West Belfast so that he can abstain from going to Westminster to represent their views to the British government. Maginness rightly asked: 'what is the point in voting for someone who sincerely promises not to represent your views?' (Note 18). The Sinn Fein leadership recognizes that its Party is facing a strong argument from its political rival on this issue. In The Irish News it reported that Sinn Fein would adopt 'a slightly more intense approach at Westminster'. Sinn Fein MPs would travel to London to meet with other parties and lobby on issues. The spokesperson added that 'it is not so much that we are getting involved in the parliamentary system, but we intend to use the system to our advantage and to the advantage of those who elect us'. (Note 19)

Sinn Fein and the SDLP have been in electoral competition since 1982, when elections for a Stormont Assembly were called. But the battle became intense a year later at the Westminster election. At this election Sinn Fein won the West Belfast seat, polled 102,701 votes or $13.4 \%$ of the vote in Northern Ireland. In terms of the split in the nationalist vote, overall it was 57:43 in favor of the SDLP. Sinn Fein was just 34,000 votes behind the SDLP. (Note 20)

At the 1984 European elections the SDLP got 22.1 per cent of the vote to Sinn Fein's 13.3\%. John Hume was elected as an MEP. In Sinn Fein's first district council election in 1985 it had beaten the SDLP in Belfast. They won seven seats on Belfast Council to the SDLP's six. Obviously Sinn Fein was now a real political force in Belfast. However, outside Belfast there was a different picture. There was a clear gap in seats between both parties in this election. The SDLP won 42 seats more than Sinn Fein. The SDLP received 17.8\% of the vote to Sinn Fein's 11.8\%.

At the 1987 Westminster elections the SDLP got 21\% of the vote to Sinn Fein's 11.4\%. In terms of the nationalist vote it was $65 \%$ to the SDLP and 35\% to Sinn Fein, a decline from 1983. Gerry Adams retained his seat in West Belfast. The next election was the 1989 local government election, when the SDLP got $21 \%$ of the vote to Sinn Fein's $11.2 \%$. The European elections of the same year saw that percentage gap widen from $25.5 \%$ to $9.1 \%$ in favor of the SDLP, seemingly a pattern of inexorable decline for Sinn Fein. John Hume was re-elected MEP. At the Westminster election of 1992 the SDLP received 23.5\% of the vote to Sinn Fein's 10\%. In terms of the nationalist vote it was 70\% to $30 \%$ in 
favor of the SDLP. Gerry Adams lost his seat in West Belfast to Joe Hendron, 184,445 votes and four seats went to the SDLP and 78,291 votes to Sinn Fein. The loss of the West Belfast seat, their only seat, was more than a symbolic blow to the Republican movement.

However, the 1993 district council elections reversed this trend. Sinn Fein polled 12.4\% of the vote to the SDLP's $22 \%$ - a 64:36 per cent split of the nationalist vote in favor of the SDLP - 1993 may be seen as the year when the Sinn Fein ceased to decline; the party's vote steadied to 80,000 votes compared to the 150,000 for the SDLP. However, the SDLP won 75 more council seats than Sinn Fein, showing that it was still the dominant nationalist party in the North. The 1994 European elections were widely seen as a victory for John Hume, validating his role in attempting to bring Sinn Fein into the political process and his pursuit of peace. John Hume got 161,992 votes and 28.9\% of the vote. Ian Paisley's lead over John Hume was slashed to 1,200 votes. Sinn Fein got 55,215 votes, 9\% of the overall vote, down considerably from the time it got nearly 100,000 at a previous European election.

The Forum election of May 1996 was to be hailed as a dramatic Sinn Fein come-back. In this election it polled its highest share of the overall vote with $15.4 \%$ to the SDLP's $21.4 \%$, a 58:42 split in the nationalist vote in favor of the SDLP, the same level as the 1983 election. The vote for Sinn Fein was 116,377 and 17 seats to the Forum (both parties received an extra two seats from the regional list). The SDLP got 160,786 votes and 21 seats to the forum. The Sinn Fein come-back was most dramatic in West Belfast, where Sinn Fein out-polled the SDLP: 22,355 votes (53.4\% of the total) compared to the SDLP's 11,087 (26.4\%), thus suggesting that Gerry Adams would regain the seat at the general election the next year. Sinn Fein also beat the SDLP in North Belfast, Fermanagh and South Tyrone, Mid Ulster, and pushed the SDLP hard in the new constituency of West Tyrone. Sinn Fein had excellent showings in Foyle and Newry and Armagh. Sinn Fein was now back in the business of posing a real threat to the SDLP's position as the dominant voice of Irish nationalism in the North.

The 1997 Westminster election was to show a determined Gerry Adams, anxious to regain his seat. In fact, The Sunday Tribune was to report that for the very first time since he led Sinn Fein into the electoral arena, Adams was to drop any references to Sinn Fein in an appeal to the voters. The Andersonstown News, (a newspaper in West Belfast) which ran the advert, merely asked people to vote for Gerry Adams. Noticeably absent was any reference to Sinn Fein or any depiction of the party's logo. Instead the advert emphasized Adam's personal role in the peace process. The advert was to show him with Nelson Mandela, Mary Robinson, Bill Clinton, Albert Reynolds and John Hume. This must be one of the few occasions in Irish politics, the writer commented, when the leader of one party has employed a positive image of the leader of his main rival to boost his own chances of getting elected. (Note 21)

The election itself was to signal another triumph for Sinn Fein. Its vote rose from $15.4 \%$ in the forum elections to $16.1 \%$ this time round. Gerry Adams regained his seat in West Belfast and Martin McGuinness (Vice-President of SF) won a seat in Mid Ulster. The SDLP's share of the vote was $24.1 \%$ of the vote compared to $21.3 \%$ in the Forum election of 1996 and it held three seats in Foyle, South Down and Newry and Armagh. It was a very good vote for Sinn Fein. In winning two seats it achieved its highest share of the vote and as far as Westminster polls went, it was to become the third largest party in Northern Ireland.

In the 1996 Forum Election the SDLP took just over 59\% of the combined nationalist vote to Sinn Fein's $41 \%$. In the 1997 General Election the SDLP's share of the combined nationalist vote rose to 60.4\%, while Sinn Fein's fell to $39.6 \%$. Despite the success of two seats it was obvious that the moment of truth in relation to the 'armed struggle' of the IRA was at hand, to ditch the armalite-ballot box in favor of the ballot box.

The council elections of the same month heralded additional success for Sinn Fein. Sinn Fein's share of the vote rose from $16.1 \%$ in the Westminster election to $16.9 \%$ this time round and it obtained 74 council seats, 23 seats more than the 1993 council election. Meanwhile, the SDLP vote fell from 24.1\% to 20.7\%. It received 120 council seats. The two parties now had less than $4 \%$ of a difference between them. For Sinn Fein this best performance ever put pressure on the IRA to call a ceasefire. In Belfast Sinn Fein got 13 seats (nearly becoming the largest party in Belfast) and the SDLP got seven. Sinn Fein got a councilor elected in South Belfast for the first time and a councilor elected for the more prosperous ward of Castle in North Belfast. The Sinn Fein performance saw them becoming the joint largest party in Belfast (along with the Ulster Unionists) and cost the Unionists control of Fermanagh, Strabane and Cookstown councils and lost the SDLP its two-decade long hegemony of Derry City council. The combined nationalist vote indicated the changing demographic map of Northern Ireland. The Unionists had only overall control of 13 of the 26 district councils. As regards the share of the overall nationalist vote, the SDLP had 55\% and Sinn Fein 45\%. Just five years previously, at the Westminster election of 1992, the SDLP had 70\% to the Sinn Fein's 30\%. In the intervening period since Adams lost his seat in 1992 the Sinn Fein vote had risen by nearly a staggering 70 per cent.

In the 1998 Assembly election the SDLP got the biggest share of the vote, outpolling the UUP receiving $22 \%$ of the vote and 24 out of the 108 seats in the new Northern Ireland Assembly. Sinn Fein got 17.6\% of the vote and 18 seats the party's performance entitled it to two seats in the ten-person Northern Ireland Executive. Whilst the election was 
seen as a victory for the SDLP, Sinn Fein had emerged as the largest party in the west of the Bann constituencies of West Tyrone, Fermanagh-South Tyrone and Mid Ulster. However, both the SDLP and Sinn Fein won five seats in Belfast.

The two elections of 2001 were to show that Sinn Fein had won the battle for the Catholic/nationalist vote over its rival. In the 2001 Westminister election Sinn Fein gained two seats to take its total up to 4, whereas, the SDLP was to end up with three seats. In this election Sinn Fein was to get $21.7 \%$ of the vote, whilst the SDLP was to get $21 \%$. The Council Elections that same year had Sinn Fein on $20.7 \%$ and the SDLP on $19.4 \%$. This was a shattering blow for the more moderate nationalist party.

In the 2003 Elections for the Northern Ireland Assembly Sinn Fein was to make election gains over its main nationalist rival: Sinn Fein got $23.5 \%$ of the vote and 24 seats and the SDLP $17 \%$ of the vote and 18 seats. In the 2004 European Election Sinn Féin saw their candidate, elected on the first count with 144,541 first preferences (26.31\%). The quota was 137,320 . With 87,559 first preferences (15.94\%), the SDLP candidate conceded early on that he wasn't in the running for the third seat.

In the 2005 general Election Sinn Fein was to retain its position as the largest nationalist party, it increased its overall vote by almost 12,000 from the 2003 Assembly election. Nonetheless, the prediction that it would win the largest number of votes proved groundless. Sinn Fein finished behind the DUP. In the 2001 general election, they jumped four percentage points to $21.7 \%$, and then 1.8 points in the 2003 Assembly Election to $23.5 \%$. The increase this time, to $24.3 \%$, was less than a percentage point. The SDLP lost Newry and Armagh, Seamus Mallon's, the former Deputy First Minister, old seat to Sinn Fein That was party's sole gain in the 2005 General Election (bringing a total of 5 seats for Sinn Fein and 2 for the SDLP). Sinn Fein remains the dominant nationalist party, capturing almost a quarter of the overall vote in this election.

\section{The Irish Republic}

There has been an uneven development of Sinn Fein. In the South it is not a main electoral contender, and the statistics demonstrate that it is a party far from the political mainstream. In the 1987 general election it got $1.7 \%$ of the vote, and no seat. In the 1989 general election it got $1.2 \%$ of the vote, and no seat. The local government election of June 1991 was to have Sinn Fein fielding 59 candidates and it won only six seats out of a total of 883 seats at stake. At the Dail election of 1992 Sinn Fein captured just 1.6\% of the vote and no seat. In the Urban District/Town Commission election of 1994 it received $4 \%$ of the vote. Throughout the entire Republic of Ireland it had only 31 councilors. It was not an electoral force south of the border. Richard Sinnott, attributes this lack of electoral success to the IRA's continuing campaign of violence and Sinn Fein's association with that campaign. (Note 22) Gerry Adams himself admitted: 'obviously the effect of the conflict here does have its effect in the 26 Counties'. (Note 23)

Sinn Fein in the South is viewed as a 'Northern party'. The Sinn Fein leadership hope to gain the support of the long-term unemployed, and those who are politically and socially alienated from the state and the third of the people in the Republic who live below the poverty line. The party's political profile is definitely on the left of the Republic's political spectrum. It supports higher corporation and incomes taxes and a substantial redistributive programme on health, education, housing and welfare. The party's appeal is pitched towards the under-privileged and average income earners. However, the problem for Sinn Fein is that there is still electoral competition for votes, and there are a number of left-of-centre parties fighting for votes, and, of course, independents.

In the 1997 Dail election the Sinn Fein 'peace strategy' was to pay electoral dividends in the South. Caoimhgmin O Caolain topped the poll in Cavan-Monaghan for Sinn Fein, receiving 11,000 plus first preference votes. Sinn Fein was to get $2.5 \%$ of the vote. O'Caolain was to be the first member of Sinn Fein to take a Dail seat as distinct from winning one. In the 2004 European elections and Local Council Elections in the Republic of Ireland Sinn Féin was to win its first European seat and Sinn Féin and was to more than double its votes and council seats compared to their 1999 results. Sinn Féin seeks political power North and South. It is the second largest party in Northern Ireland and has ambitions to become the largest all-Ireland party in coming years. In the Republic it has held the support of about 10 per cent of voters, according to successive opinion polls.

\section{Endgame}

In Padraig O'Malley's Northern Ireland: Question of Nuance, Gerry Adams considered the support for the 'armed struggle' in Ireland:

"I don't think there's anyone who could turn around and say that the majority of people do not support the armed struggle. There's a tolerance, there's ambivalence, there's an ambiguity, there's a wink and a nod - these are all the old effects of our colonial past ..." (Note 24)

The same book had Danny Morrison stressing that, in terms of the necessity of a popular mandate for armed struggle, the mandate came from a 'higher power' (presumably God, or the dead generations, or the mandate of history, although 
Morrison does not say). He went on to say that there is 'no question' of the people having 'the right to be wrong' on the national question. Looking back through Irish revolutionary history, Morrison concluded that at no point was a popular mandate sought by those waging the struggle.

Although the vast majority of Irish nationalists repudiate the views and sentiments of Adams and Morrison in relation to 'armed struggle', nonetheless, Sinn Fein had sought to exploit any uncertainty, ignorance and confusion that may exist in nationalist Ireland with regard to the relationship between Sinn Fein and the IRA and the contention that Sinn Fein is a genuine political party that is bona fide committed to the democratic process. Even Ruairi O'Bradaigh, arguably the person most identified with traditional republicanism, recognizes in relation to democratic methods and the physical force tradition that 'if you try to ride two horses in different directions at the same time, you will be pulled apart'. (Note 25) This yawning gap between the Sinn Fein protestations on one hand, and the actions of the IRA on the other, was to lead to an inexorable and decisive formal split between the political wing and the military wing of the Republican movement.

The dilemma and pressing reality of the situation that Gerry Adams and the others in Sinn Fein faced was that the British government, Irish-American opinion, and, particularly, mainstream Irish nationalism would not be shifted from the position of demanding a genuine commitment to democracy and democratic methods.

On July 20, 1997 the Provisional IRA declared another 'complete cessation of military operations'. On Good Friday, 10 April, 1998 the all-party talks at Stormont finally reached an agreement. It contained amongst other things:

Power-sharing, parallel consent, proportional representation, a Bill of Rights, a Human Rights Commission, the European Convention on Human Rights, an Equality Agenda, a Commission on Policing, the release of prisoners, a review of the criminal justice system, a Civic Forum and cross-border bodies.

On July 1, 1998 Sinn Fein took its seats in a new Northern Ireland Assembly; and on September 1, 1998 Gerry Adams, in a key note statement, was to declare that 'Sinn Fein believe the violence we have seen must be for all of us now a thing of the past, over, done with and gone'. (Note 26)

The IRA has declared two ceasefires without any declaration of intent to withdraw from Northern Ireland by the British government. Sinn Fein has taken its seats in a new Northern Ireland Assembly and has taken part in the governing of Northern Ireland. In signing up to the Good Friday Agreement Sinn Fein has accepted that the constitutional status of Northern Ireland can only be changed by the consent of the majority of the people in Northern Ireland. It accepted the removal of Articles 2 and 3 of the Irish Constitution and it is faced with the reality that cross-border bodies are not 'free standing' but subject to the control of a Northern Ireland Assembly.

The above surely represents the abandonment of fundamental core principles on the part of the Provisional Republican movement. However, for Sinn Fein to be taken seriously as a 'normal' democratic party it had to divest itself of the IRA; and it has to abandon its abstentionist culture. After 35 years of 'armed struggle' the IRA was to end its war. In the July 29, 2005 the IRA were to declare a formal end to its armed campaign. All IRA units were ordered to dump arms; and the IRA vowed to complete its long-running decommissioning process. On the September 26, 2005 the head of the international decommissioning body was to declare that the IRA's entire arsenal of weapons has been destroyed.

Nonetheless, there needed to be a further, final act of transformation from the Provisionals. Sinn Féin had to endorse the new Police Service of Northern Ireland (PSNI), the reformed RUC, which was the main target of IRA attacks during the Troubles. At a special party conference on the January 28, 2007 Sinn Fein was to do this. The Sinn Féin ardfheis motion on policing read:

Sinn Féin reiterates our support for An Garda Síochána [Irish Police] and commits fully to:

- Support for the PSNI and the criminal justice system.

- Authorize our elected representatives to participate in local policing structures in the interests of justice, and actively encouraging everyone in the community to co-operate fully with the police services in tackling crime in all areas and actively supporting all the criminal justice institutions. (Note 27)

An overwhelming majority backed a motion giving the leadership the power to participate in Northern Ireland's policing and justice structures. The decision overturned a century of opposition to any British policing presence in Ireland. There were no walkouts by disaffected members. The final vote showed little more than $5 \%$ of delegates were opposed to the leadership. (Note 28)

Sinn Féin was to conclude its journey towards endorsing policing in Northern Ireland when its three representatives joined the new Policing Board. (Note 29) The DUP and Sinn Fein were to emerge as the clear winners in the 2007 Assembly elections. Sinn Fein in this election got 28 out of the 108 seats (up 4 on the last Assembly election) and got $26.2 \%$ of the vote (up $2.6 \%$ on the last Assembly election). The SDLP had 16 seats (minus 2 on the last Assembly Election) and got $15.2 \%$ of the vote (minus $1.8 \%$ on the last Assembly Election). 


\section{Conclusion}

The DUP and Sinn Fein had signaled their willingness to enter government and form an executive; the DUP by confirming the Rev Ian Paisley was prepared to become First Minister and Sinn Féin by endorsing the criminal justice system and the Police Service of Northern Ireland. After four years of stalling powersharing government resumed in Northern Ireland on May 8, 2007 after an historic agreement between Gerry Adams and Ian Paisley. The DUP, with four ministries, will be in charge of: finance and personnel; enterprise, trade and investment; environment; and culture, arts and leisure. Sinn Féin, with three departments, will have: education; regional development; and agriculture. Ian Paisley became First Minister and Martin McGuinness, former Chief of Staff of the IRA, became Deputy First Minister.

Republican dissidents, have this time, united to end 'armed struggle'. The real IRA, the Republican dissident group that was responsible for the Omagh bombing, was to renounce violence having agreed with the Irish National Liberation Army and the Continuity IRA on a peaceful Northern Ireland strategy. It has been forced to accept that there is a mass of opposition to political violence even among working-class republicans. An INLA source also confirmed that the three groups were united in acknowledging that there was no support for armed struggle. 'It's time we listened to the people and gave them a real political alternative,' the source said. (Note 30)

Leading up to the May 2007 election in the Republic of Ireland. Sinn Fein had five British MPs, five members of the Irish Parliament and two MEPs (one in the North the other in the South). It was regarded as the fastest growing political party on the island of Ireland. Just three weeks after forming an historic coalition with the DUP in Northern Ireland, Sinn Fein was to suffer a demoralizing electoral setback in the Irish Republic. Sinn Fein wanted to double its representation in Ireland's parliament, the Dail, putting it in government on both sides of the Irish border. Some polls had predicted that the party could win up to 15 seats. Indeed, Martin McGuinness had predicted that Sinn Fein would be 'The Story of the Election'. However, it only managed to cling on to four of the five seats it held before polling day. With around 10\% support consistently in the opinion polls the party should have done better much better.

Sinn Fein's poor poll results highlight the importance of the economy to voters in the Irish Republic. The electorate in the Republic of Ireland proved to be more interested in domestic economic performance, health, education and transport than constitutional issues in Northern Ireland. Having experienced the benefits of the economic prosperity under the 'Celtic Tiger', voters were unimpressed by Sinn Fein's left-wing approach and uncertain economic principles, which saw policies jettisoned in the search for votes. Typical of this was the dropping of their policy of adding five per cent to the 12.5 per cent rate of corporation tax. Paul Bew, Professor of Irish Politics at Queen's University, Belfast, argued: "The result shows how deeply rooted partitionist attitudes really are. For the people of the Republic, in this election what mattered was the internal politics of the state. The attempt to introduce other issues such as Irish unity by Sinn Fein was a complete failure". (Note 31)

An article in the opinion section of the Irish Times entitled: Election performance in South has damaged SF brand, was to state: "Being the second largest party in a centrist, cross-party, Paisley-led government in Northern Ireland is a long way from achieving the 32-county socialist republic for which the Republican Movement (Sinn Fein/IRA) struggled for". It added that Sinn Fein has had to accept the principle of consent and face up to 'the reality that Ireland is partitioned and will be for the foreseeable future'. In order to exercise power, it has had to enter government in a Northern Ireland within the United Kingdom. It went on to say that Sinn Fein sought to 'assuage discontent among volunteers and supporters' by leading them to believe that the party was on the 'verge of being in government on both sides of the Border', that the party's Westminster MPs would sit and speak in the parliament in the Irish Republic and even that 'Gerry Adams would be president of Ireland by the time the centenary of the 1916 Rising came around'. (Note 32)

By endorsing the police service, the courts and the wider system of justice in Northern Ireland Irish republicanism has, in effect, decommissioned its own ideology. Sinn Fein has made this 'historic' ideological transformation so that it can share power, with the Democratic Unionist Party. In a similar vein, as a consequence of dropping it's the policy of redistribution via increased corporate taxation in the 2007 election in the Irish Republic, in an attempt to facilitate a role in government for the party in the Irish Republic, Sinn Fein has also ditched socialism.

For Sinn Fein the ultimate prize was simultaneously holding power across Ireland in a power-sharing assembly in the north and a coalition government in the south. However, as a consequence of the 2007 general election in the Irish Republic, Sinn Fein's strategy to push for a united Ireland by using ministries in both Belfast and Dublin is now in ruins.

\section{References}

Adams, G. (1986). The Politics of Irish Freedom. Kerry: Brandon Books.

Bell, J Bowyer. (1979). The Secret Army: The IRA 1916-79. Dublin: Irish Academic Press.

Clarke, L. (1987). Broadening the Battlefield - The H-Blocks and the Rise of Sinn Fein. Dublin: Gill and Macmillan. 
Clarke, L. (1994). Contemporary Republican Politics. In B. Barton, \& P. J. Roche (Eds). The Northern Ireland Question: Perspectives and Politics. Avebury: Ashgate.

Coogan, T.P. (1995). The Troubles: Ireland's Ordeal 1966-1995 and the Search for Peace . London: Hutchinson Press.

Cox, M; Guelke, A, and Stephen, F. (2000). “A Farewell to Arms? From 'Long War' to Long Peace,” Northern Ireland. Manchester: Manchester University Press.

Dixon, P. (2001). Northern Ireland - The Politics of War and Peace. London: Palgrave.

Hume, J. (1996). Personal Views: Politics, Peace and Reconciliation in Ireland. Dublin: Roberts Rinehart Publishers. Mallie, E and McKittrick, D. (1996). The Fight for Peace: The Secret Story Behind the Peace Process. London: Heinemann Press.

Maillot, A. (2005). New Sinn Fein - Irish Republicanism in the twenty-first century. London: Routledge.

McGarry, J and O'Leary, B. (1995). Explaining Northern Ireland. Oxford: Oxford University Press.

Moloney, Ed. (2002). A Secret History of the IRA. London: Allen Lane.

Murray, G and Tonge, J. (2005). Sinn Fein and the SDLP - From Alienation to Participation. London: Palgrave.

O'Brien, B. (1993). The Long War - The IRA and Sinn Fein 1985 to Today. Dublin: O’Brien Press.

O Connor, F (1993). In Search of a State: Catholics in Northern Ireland. Belfast: Blackstaff Press.

O'Leary, B. \& McGarry, J. (1996). The Politics of antagonism: Understanding Northern Ireland. London: The Athlone Press.

O'Malley, P. (1990). Biting at the Grave, The Irish Hunger Strikes and the Politics of Despair. Belfast: Blackstaff Press.

O'Malley, P. (1990). Northern Ireland Questions of Nuance. Belfast: Blackstaff Press.

Purdie, B. (1990). Politics in the Streets - The Origins of the Civil Rights Movement in Northern Ireland. Belfast: Blackstaff Press.

Ryan, M. (1994). War and Peace in Ireland - Britain and Sinn Fein in the New World Order. London: Pluto Press.

Sinnott, R. (1995). Irish Voters Decide - Voting Behavior in Elections and Referendums Since 1918. Manchester: Manchester University Press.

Tonge, J. (2005). The New Northern Irish Politics? London: Palgrave.

White, J. (1990). Interpreting Northern Ireland. Oxford University Press: Clarendon Paperbacks.

\section{Notes}

Note 1. Bell, J Bowyer. (1979). The Secret Army: The IRA 1916-79. p 334.

Note 2. Interview with Gerry Adams taken in 1989.

Note 3. Adams, G. (1986). The Politics of Irish Freedom. p 8.

Note 4. This refers to Sinn Fein's policy of abstaining from sitting in, or standing in, elections for Westminster, the Southern parliament and the parliament of Northern Ireland. By pursuing such a policy republicans are challenging the legitimacy of these parliaments. Pre-1986 Sinn Fein only stood in election to harness protest votes. Since partition for republicans was deemed illegitimate and undemocratic they would not grant any partitionist assembly recognition.

Note 5. I refer here to those traditional republicans who had maintained the Republican movement before the New Departure in the 1960s. The republican policy of abstentionism was for these people sacrosanct, an article of faith. For these purists the political option had corrupted Irish republicanism. The use of arms to put the 'British out of Ireland' was for purists the only realistic and trustworthy method available. For an authoritative account of this old guard with its traditionalism and distrust of politics see Bell, J Bowyer, op. cit.

Note 6. Clarke, L. (1994). Contemporary Republican Politics. In B. Barton, \& P. J. Roche (Eds). The Northern Ireland Question: Perspectives and Politics. p84.

Note 7. Clarke, L. (1987). Broadening the Battlefield - The H-Blocks and the Rise of Sinn Fein. p208.

Note 8. See Hume, J. (1996). Personal Views: Politics, Peace and Reconciliation in Ireland. Dublin: Roberts Rinehart Publishers.

Note 9. Talks between the SDLP and Sinn Fein had begun in 1988 but were to break up over ideological differences. Sinn Fein's had wanted the SDLP and the Irish government to force the British to declare a declaration of intent to 
withdraw from Ireland and for the British to persuade the Ulster unionists to accept the inevitable Irish unity. See: Clarke, L, (1994). Contemporary Republican Politics. p94.

Note 10. Mallie, E and McKittrick, D. (1996). The Fight for Peace: The Secret Story Behind the Peace Process. p145.

Note 11. Mallie, E and McKittrick, D. (1996). The Fight for Peace: The Secret Story Behind the Peace Process. (see the Appendix section).

Note 12. The Irish News, August 13, 1994.

Note 13. The Irish Times, September 7, 1994

Note 14. Interview with Geraldine Taylor taken in 1994.

Note 15. Interview for The Belfast Telegraph, October 21, 1994.

Note 16. Interview with the IRSP leadership taken in 1996.

Note 17. Mallie, E and McKittrick, D, (1996). p322.

Note 18. The Belfast Telegraph, April 2, 1997.

Note 19. The Irish News, April 2, 1997.

Note 20. 'Electoral Facts and Strange Fellows', Fortnight Magazine (Irish publication), March 1997. Electoral statistics for electoral results in Northern Ireland and the Republic of Ireland were gathered from Irish Newspapers: The Irish News, The Irish Times, The Belfast Telegraph, and The Sunday Tribune. Opinion polls as to the current state of the parties were also gathered from these sources.

Note 21. The Sunday Tribune, April 20, 1997.

Note 22. Sinnott, R. (1995). Irish Voters Decide - Voting Behavior in Elections and Referendums Since 1918. p 61.

Note 23. The Belfast Telegraph, March 18, 1997.

Note 24. O'Malley, P. (1990). Northern Ireland Questions of Nuance. $\mathrm{p} 55$.

Note 25. The Belfast Telegraph, October 21, 1994.

Note 26. The Irish Times, September 2, 1998.

Note 27. The Irish Times, January 15, 2007.

Note 28. The Guardian (British Newspaper), January 29, 2007.

Note 29. The Irish Times, June 1, 2007.

Note 30. The Observer (British Newspaper), May 20, 2007.

Note 31. The Observer (British Newspaper), May 27, 2007.

Note 32. The Irish Times, June 30, 2007. 